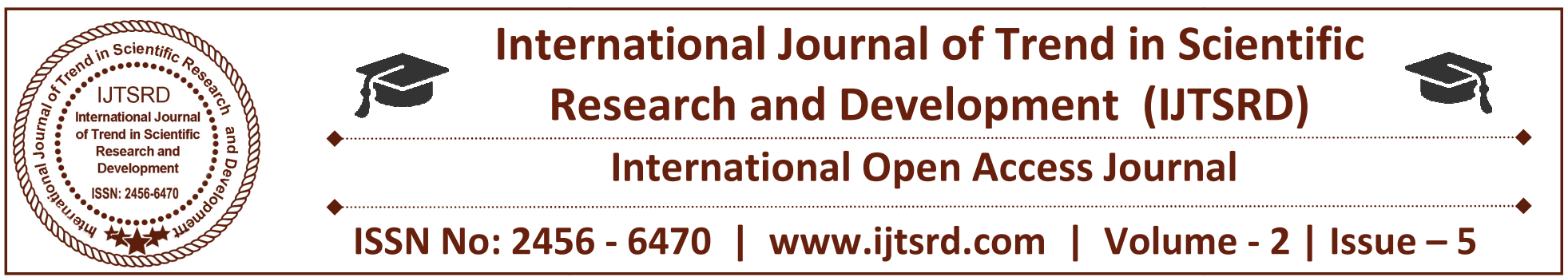

\title{
Role of Teachers in Nation Building
}

\author{
Dr. Jaimin Patel \\ Assistant Professor, Faculty of Commerce, Ahmedabad, Gujarat, India
}

\begin{abstract}
The study is aimed at evaluating the roles of teachers in National Development. It is obvious that qualified competent and dedicated teachers are the major instrument for achieving educational goals and National Development. They are often molested and abused by students, parents and the entire society. Nevertheless, through teacher education, teachers have contributed to national developments like election, census. They also participate in creating awareness among the citizens. Teachers are the real agents that help in the development of various skills and competencies. It should be noted that the more good teachers the nation has, the more the solid citizens and hence more development of the country.
\end{abstract}

\section{INTRODUCTION}

Teachers are the future builders of our country; they are the providers of knowledge and wisdom. They are the basic source of education for most of the people of the country and they are the ones who build the future of the nation. The teachers can very easily decide what they want the nation to look like and educate the masses accordingly. They have the ability and the strength to fight the odds and make India a powerful and a well educated country. A nation is built by its citizens, citizens are moulded by teachers and teachers are made by teacher educators. Chanakya has rightly stated, "Teacher is the maker of nation" So for the development of the country, it is very important to have good teachers and good teachers can be produced only if we have a good system of teacher education and dedicated and efficient teachereducators. The teacher can be rightly called a nation builder. Teachers through their perseverance love and sacrifices have shown us the right path in which great men have built our nation. It is our dear teachers who mould our character, our personality and show us the right direction which leads us to our Final destination.
No other personality can have an influence more profound than that of a teacher. Students are deeply affected by the teacher's love and affection, his character, his competence, and his moral commitment. A popular teacher becomes a model for his students. The students try to follow their teacher in his manners, customs, etiquette, style of conversation and his get up. He is their ideal. He can lead them anywhere. During their early education, the students tend to determine their aims in life and their future plans, in consultation with their teachers.

\section{REVIEW OF LITERATURE:}

SunitaKumari (2016), a quality teacher's education program is rational and streamlined to address some specific pedagogical issues. Basically, it elucidates the idea about what good teaching is all about and then how it organizes course work and all practical experiences around it. Teacher's education courses are very much connected to practice as well as to theory. A good teacher's training programs have teachers working continuously with expert master teachers in a traditional classroom or virtual setting to enhance the knowledge and experience base.

Aneja (2015), this paper suggest that for a developed India, an important thrust should be on the growth of the invisible leaders and innovative institutions/universities/colleges/research institutions. Hence, there is an urgent need to establish and efficient innovation system and let the universities act as bridging institutions like think tanks.

Ekpikenand Edet (2014), in this paper the researcher adopted survey design approach through the use of questionnaire developed and validated by the researchers and two experts in measurement and evaluation course. The sample consisted of 118 
respondents who are Cross River State indigenes. The data was analyzed using Pearson product moment correlation coefficient. All the hypotheses were tested at 0.05 level of significance. The result indicates that there is a relationship between Nigerian teachers' professional roles and national development.

Imam (2011), this article provides an overview of teacher education and evaluation in India and lastly we discuss about issues and challenges in teacher education. Several studies related to classroom environment and teacher behavior in selected subjects are referenced. The results from different papers and articles and some interview with teachers from different schools and colleges indicate that some items may be irrelevant in the Indian context (e.g., physical characteristics), while more items may be needed to reflect good teaching in India (e.g., questioning skills). In addition, the potential use of teacher profiles to drive staff development and academic improvement is explored.

\section{Objective of the Study:}

To examine the role of teachers in national building. And which role teachers required playing in development of the nation.

\section{Role of Teachers:}

Teachers have a vital role in nation building because the future is totally in their hands. They choose to be the fortune builders of the country and if you really want to know how important teachers are for their country, try imagining a nation without them. It will only be a nation of utter chaos where nobody would step up to make sure the kids get the best education and the knowledge to sustain a good and healthy life. The nation will no longer be able to progress and the population will be sick. Here are a few characteristics of the roles that our teachers play every single day.

Making the children ready for a challenging life it starts at a very early age, the teachers take the kids away from their parents for a few hours and teach them in a total different environment. They try and make the environment as friendly as possible, but it is still different from the environment at home. Knowingly or unknowingly, teachers prepare the kids for unknown environment which they might have to face in their lives.

Literacy and wisdom - The teachers not only make the child literate so that he/she can earn enough to have a normal lifestyle, they also provide words of wisdom every day which shape the personality of the child. Many children are influenced by their teachers more than the parents. A teacher is mostly selfless and believes in dissipating whatever information he/she can to make the kid wiser than yesterday.

A friend, philosopher and guide - Today we can see that teachers have moved on from the basic image of a strict teacher, they have become much more for their students. They provide a friendly shoulder to cry on when the kid is in a problem, they tell about the philosophies of life so that the child could take lessons and apply to his/her own life and they guide the child to follow the right path. The teachers have the courage to push the kid to do what they want to, even if it has never been done before.

Well-wishers - No other job makes a person worried if a child's parent is divorced, a drunk or a wife abuser. Teachers are the ones who have full knowledge of the child's life, the environment back home, his mindset and his capabilities. They always try and strike a balance between all of these things and make sure that the kid's future doesn't get affected in a bad way.

Nation builder - A nation comprises of the children way more than adults. The children are the future and the teachers are the ones who are getting them ready for their task. With optimum education, wisdom, exposure and resources, the teachers are building the nation for tomorrow brick by brick and the foundation is so solid that the nation will only grow upwards.

Teaching as a profession is probably the most challenging because it combines all the other professions in order to help a child grow. One has to have good communication skills, managerial skills, reading and writing skills, storytelling skills, everything. The teachers have selflessly and courageously chosen the path where they will always be working for the mankind and for its good. Not everybody has the heart to do it. The leaders of today are getting the leaders of tomorrow ready.

\section{Problems Faced by Teachers:}

\section{Difficulty in Monitoring the entire class:}

Most of the time we teachers are unable to pay attention to every student particularly, in the rush to complete the lessons on time. This is mostly because of the mischievous students, sitting in the front rows, 
who tend to disturb the teachers during ongoing lessons. This in turn, makes us unable to attend the students who sit at back benches or other students in the class who wish to learn. As a consequence, the teacher completes the curriculum somehow, making the students skip the understanding part. This adversely affects the class performance.

\section{Involvement of Parents:}

It becomes really difficult for the school teacher, if the child's parents do not collaborate with them on the educational front. The problem with US parents is that either they are very busy with their own lives or they lack proper education, as a consequence of which, they are unable to pay attention to their children's educational progress. In fact, I have seen parents disfavoring the concept of home assignments. Most of them complain, that the assignments given to their children are beyond their scope of knowledge and they cannot guide their kids for completing the home assignments. Being a teacher myself, I never expect parents to have knowledge about the child's assignment, but what I really want from them, is their support, to motivate the child to complete the assignments themselves and on time. Due to the lack of this support from some parents, the teachers fail in helping their children in understanding the concepts effectively. Moreover, a majority of parents do not involve themselves in parent's meetings and activities organized by the school. I have observed few of my students' parents to be similar. Honestly, without proper discussion with the parents, it becomes very tough for me to strengthen their child academically. All these factors majorly affects the students' overall performance in class. Therefore, communication between parents and teachers should be improved.

\section{Monetary Concerns:}

The amount of salary we receive from the school, doesn't have the capability to restrain us from bankruptcy after retirement. After clearing debts, paying for instalments, car, food and daily requirements along with increased taxes, pay cuts, and bills, there is not a penny left with us at the midst of the month. This is a huge problem for teachers as financial stability is a primary requirement for maintaining their peace of mind.

\section{Lack of Support:}

The institute keep conducting tests multiple number of times in the entire year. They come to big conclusions about the students' learning based on just their scores. But that is not the ultimate measure to judge a child's abilities, instead the child should be given adequate learning materials, proper infrastructure and teacher's support.

\section{Lack of Motivation:}

Teachers play extremely crucial role in shaping the young mind, during the FORMATIVE years, starting from pre-primary to secondary school, and yet most societies in the world, do not position school teachers, at a level that they deserve, in laying foundation to the future society. Under-positioning of the role of school teachers, leads to lower motivation culminating into reduced level of passion/commitment.

\section{Pace of Change:}

World is changing at a rapid pace and there's a need for teachers to learn as well, for instance, new way of teaching or engaging with subject using technology. In my experience, most school teachers are not updated to engage with students of today. The students are born in an environment that is far more information intensive than ever before and unless teachers are capable to comprehend the latest, they cannot enable students in learning for future. I did express my views on this subject earlier through my blog in March, 2013, albeit blog was focused on higher education and not school.

\section{Conclusion:}

Teacher education and teachers are the major instrument for achieving educational goals and national development hence no nation can rise above the standard of its educational system. This write up observed that teachers are not given their respect in the society, they are molested, sometimes harassed, intimated and humiliated by shameless and heartless parents and government officials and have lost their collective prestige to the greedy and over ambitious society. Notwithstanding, teachers contribute to the development of the nation in areas of, supply of manpower to the various sectors of national economy, they ensure good discipline and high moral plane of pupils who are future leaders of tomorrow. The teacher is the real agent that helps in the development of various skills and competencies thereby enhancing self-employment and self-efficiency.

\section{References:}

1. William E. Ekpiken, Aniefiok O. Edet (2014),"The Role of Teacher Education and Nigerian Teachers In National Development: The 
Way Forward", Higher Education of Social Science Vol. 7, No. 1, 2014, pp. 139-143.

2. DR. NeenaAneja (2015), "Role Of Teachers In Nation Building", Journal Of Information, Knowledge And Research In Humanities And Social, ISSN: 0975 - 6701, Volume 3, Issue 2.

3. Fayose, P. O. E. (2003), Children, teachers and librarians: Developing information conscious children. Inaugural lecture delivered at University of Ibadan.
4. Kothari, D. S. (1966) (Chairman) Report of the Education Commission 1964-66. Govt. of India, New Delhi.

5. Imam (2011), "Quality and Excellence In Teacher Education: Issues \& Challenges In India", International Journal of Multidisciplinary Research Vol.1 Issue 7, November 2011, ISSN 22315780.

6. SunitaKumari (2016), "Quality, excellence and challenges in teacher education in Era of globalization", International Journal of Applied Research 2016; 2(10): 34-37.

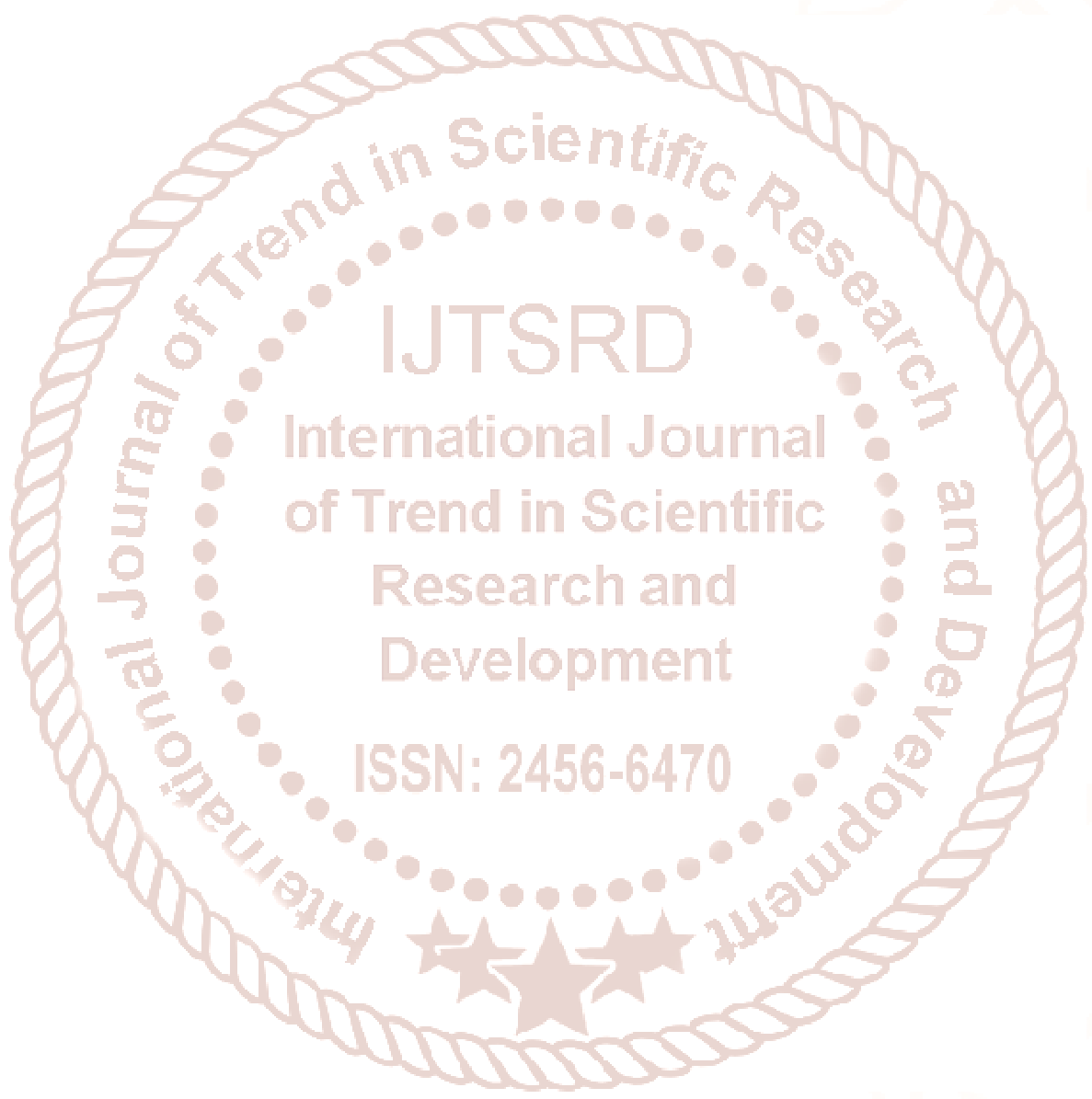

